Studia Slavica Savariensia 2016. 1-2. 72-77

DOI: $10.17668 /$ SSS.2016.1-2.72

Timea Bockovac

(Pečuh, Mađarska)

\title{
AKTUALNI ZADACI JEZIČNE POLITIKE HRVATA U MAĐARSKOJ
}

\begin{abstract}
The present paper discusses the concept, place and role of language policy as part of the interdisciplinary science of applied linguistics. In the context of language policy of the European Union, there is always discussion about the Hungarian practice, especially in the segment of minority language rights, and the possibility of the minority language policy. Among the current tasks of the language policy of Croats in Hungary there is especially the need for a language strategy and empirical research emphasized, that may contribute to language planning. Apart of planning the status and corpus, there is much emphasis put on the planning of the language reacquisition, as well as of developing the state of balanced bilingualism.
\end{abstract}

Keywords: sociolinguistics, linguistic reality, Croats in Hungary, language policy, language planning

\section{Uvod}

U naslovu određeno područje jezične politike spada pod sociolingvistiku koja pak čini dio interdisciplinarne znanosti primijenjene lingvistike. Primijenjena lingvistika proučava odnos između jezika i društva, jezika i djelovanja, jezika i uma te jezika i ljudske individualne i kolektivne svijesti, te primjenom lingvističke teorije i njezinih spoznaja na pojašnjavanje i rješavanje jezičnih problema koji se javljaju u nekim drugim bliskim praktičnim područjima. Korespondirajuće znanosti su joj antropološka lingvistika, jezična politika, dijalektologija, etnolingvistika, istraživanje jezičnih kontakata te jezična sociologija.

\section{Jezična politika}

Jezična politika je relativna mlada disciplina (1960), ali provođenje jezično političkih postupaka ima drevnu tradiciju, jezično političkim djelatnostima državne institucije nastoje nadzirati i mijenjati jezičnu praksu ili ideologiju. Ove djelatnosti u prvome su redu usmjerene na razvoj, očuvanje, uporabu, učenje i širenje nacionalnih idioma te potvrđivanje njihova službenoga statusa. U širemu smislu odnose se i na druge jezične resurse u državi (nestandardne idiome, idiome nacionalnih manjina ili useljenika), kao i na učenje i širenje drugih nacionalnih idioma (tzv. učenje stranih jezika). Škiljan u svojoj definiciji ističe kako je to "skup racionalnih i uglavnom institucionaliziranih 
postupaka kojima neko društvo utječe na jezične oblike javne komunikacije i na formiranje svijesti svojih sudionika o tim oblicima" (ŠKILJAN 1998: 88). Istaknuta područja jezične politike su: deklarirana jezična prava, jezična diskriminacija, komunikacijski konflikti, odnos službenoga i manjinskoga jezika, podučavanje stranih jezika.

Razlikujemo nekoliko vrsti jezičnih politika, najosnovnija je podjela na jednojezičnu i višejezičnu politiku, dok je najčešća na eksplicitne i implicitne jezične politike. Eksplicitne jezične politike točno određuje pravila etnolingvističkih skupina, dok implicitne (prešutne) jezična prava manjina ne definiraju posebnim pravnim dokumentima, nego se oni mogu iščitati samo iz općepravnih tekstova (poput ustava), koji ne reguliraju isto detaljno ili konkretno. Postoji još i podržavajuća jezična politika - ona osigurava uporabu jezika ustavnim, administrativnim i pravnim instrumentarijem, određuje i osigurava djelokrug te jamči i potrebita financijska sredstva - i miješana jezična politika prema kojoj većina demokratskih država tolerira manjine i osigurava, tj. zakonom regulira - njihova jezična prava, ali prvenstveno podržavaju većinski jezik. Tolerantna jezična politika ne ograničuje uporabu manjinskih jezika, ali ni ne određuje posebna sredstva za njih, kao ni spektar njihovih uporaba. Prema egalitarnoj jezičnoj politici svi su jezici ravnopravni, pa se svi svugdje i koriste.

Zaključno: jezična politika je zbir pravila pojedinih država koji se odnose na uporabu jezičnog repertoara govornika. Zadatke jezične politike određuju društveno uređenje date države, društvene klase, politike, ideologije i jezična situacija. Važno je napomenuti i jezičnu geopolitiku, kao skup jezičnopolitičkih postupaka koji nastaju uslijed zemljopisnih kontakata, kao temeljno pitanje tu se javlja pitanje statusa jezika, uloga jezika i regionalna uporaba, pitanje jezičnoga identiteta, pitanja dvojezičnosti i višejezičnosti.

\section{Jezična politika Europske Unije}

U globaliziranom svijetu današnjice kao i u multikulturalnoj europskoj sredini se na teoretskoj razini sve veći naglasak stavlja na sačuvanje etničkih raznovrsnosti i jezika, međutim birokratska praksa, pa i financijski pokazatelji provedbu načela jednakosti svih europskih jezika znatno osporavaju, pa i onemogućuju. Na taj način demokratsko i tržišno načelo stoje u oprjeci i razvijaju dvopolnu strukturu, a dok se možebitna jezična politika EU zasniva na naglašavanju višejezičnosti, iz jezične je prakse jasno vidljivo koliko prednjače neki jezici, a posebice engleski kao nova lingua franca našega vremena.

Jezici EU dijele se na službene, radne, regionalne, manjinske, a treba razlikovati i status malih, ali i državnih jezika od statusa autohtonih ali bezdržavnih jezika. Uslijed te jezične šarolikosti najpopularnija europska jezična politika je politika dvojezičnosti, premda prema Györgyu Szépe Europska Unija zapravo i nema svoju jezičnu politiku, a i izostanak formalne jezične politike također je nekakva jezična politika, ali prvenstveno 
etnolingvističke manjine postaju dvojezičnima kojima je osigurana edukacija sa značajnom prevagom većinskog jezika (SZÉPE 2001: 210). Osim sudbonosnih promjena društveno-političkih prilika u Europi, u proteklih dvadesetak godina značajno se promijenila jezična stvarnost u Mađarskoj, a i u Hrvatskoj. U Mađarskoj je došlo do prestanka obvezatnoga učenja ruskoga jezika, koji je činio dio onodobnoga jezičnoga imperijalizma, u Hrvatskoj je jezična zbilja bila uvjetovana ratnim i poratnim događanjima, iza tih jezičnih promjena također se kriju razne vrste jezičnih politika koje se grupiraju prema posebnim kriterijima.

\section{Mađarska jezična politika i manjine}

Aktualna vlast ima neusporavajući utjecaj na uporabu jezika. Mađarska je među potpisnicima Europske povelje o regionalnim i manjinskim jezicima (1992., 1998.), a i u (novom) mađarskom ustavu (2011.) se na više mjesta donose odredbe o uporabi jezika već i u Preambuli gdje stoji: „prihvaćamo zadatak prenošenja vlastite baštine na nova pokoljenja, jedinstvenog nam mađarskog jezika i kulture, kao i jezika i kultura narodnosti kao i prirodom date $\mathrm{i}$ od čovjeka stvorene vrijednosti u Karpatskom bazenu, koje ćemo njegovati i sačuvati" da bi se kasnije u stavku pod brojem XXIX. istaknulo „Narodnosti koji žive na području Mađarske raspolažu pravom na svoj materinski jezik, na uporabu osobnog i kolektivnog naziva, na njegovanje svoje kulture i na školstvo na materinskom jeziku." (MAGYARORSZÁG ALAPTÖRVÉNYE 2016: 39)

Osim ustava i ustavnih zakona i Zakon o narodnostima (2011.) jamči pripadnicima manjina služenje svojim jezikom i pismom u privatnom i javnom životu, s jedne strane je broj zajamčenih prava sve veći, međutim ipak pratimo pojačanu asimilaciju, razlog tomu je možda i to da ustav obično osigurava uporabu jezika, ali skoro uvijek i ograničava to zakonima i propisima. Pojedinac se prvenstveno definira kao državljanin jedne zemlje, a poslije kao pripadnik manjinske skupine. Upravo je jezik onaj sustav simbola, koji će se naučiti unutar zajednice, ali tijekom socijaliziranja pojedinca ta identifikacija se može promijeniti pogotovo danas kada se primodalna važnost pripadanju jednoj zajednici opada, dok nastaje nova kategorija govornika s dvojakim jezičnim identitetom.

Jezična politika ima značajnu ulogu u životu svake manjine, jer su manjine izložene etnicizmu i lingvicizmu, te njihova prava uveliko ovise o pravnoj pozadini među kojem ima relativno malo dobrih primjera u praksi, naime većina postupaka služi homogenizaciji. Prema Szépeu „manjine si rijetko mogu dopustiti luksuzno stanje jednojezičnosti“ (SZÉPE 2001: 215), već i semantično polje izraza manjina nosi u sebi stigmatiziranost, podređenost $\mathrm{i}$ hijerarhiziranost. Manjina ima raznovrsnih, npr. nacionalna, jezična, vjerska, rasna, imigrantska, etnička, premda njihova definicija nije općeprihvaćena i točno razrađena. $U$ višenacionalnim sredinama okvirna jezična prava manjina reguliraju međudržavni sporazumi, ugovori i deklaracije, međutim oni su samo 
smjernice, bez sankcija i bez konačnih rješenja. Polazeći od prihvaćene teze kako je jezik dokaz kulturno-povijesnoga identiteta i neophodno sredstvo formiranja svijesti o identitetu, a dodajući i to kako postoje stereotipije o jezicima, temeljem kojih se stvara mit o prestižu pojedinih izabranih jezika na kraju se javljaju i unutar jedne države različiti statusni tipovi jezika.

Poznati slavist, Gustawson izvršio je sociolingvističku tipologizaciju slavenskih jezika, njegovo polazište je da u svakoj europskoj zemlji žive Slaveni koji čine manjinu u datoj zemlji, a nisu autohtoni, znači oni pretežito žive u neslavenskim državama te dolaze $u$ kontakt $s$ većinskim jezikom koji se uveliko razlikuje od manjinskoga. Manjinski slavenski jezici se nadalje dijele na one koje imaju matičnu zemlju i na one koje to nemaju, stoga se nazivaju još i mikrojezicima. Oni imaju svoju pismenost, ali su dosta izolirani, npr. gradišćanskohrvatski jezik. Jezično stanje govornika tih jezika može biti četverostruko: s obzirom da moraju poznavati svoj dijalekt, a i standardizirani oblik, odnosno mjesni govor većinskog jezika, a i njegov standard također. Za slavenske jezike u dijaspori karakteristična je pojava tetraglosije, tj. četverojezičnosti (GUSTAWSON 2001).

Prema toj podjeli kod Hrvata u Mađarskoj bi pojava višejezičnosti trebala biti prirodna, ali Mađarska je u velikoj mjeri jednojezična zemlja, o tome svjedoči i indeks jezične varijabilnosti, koji iznosi 0,033, dakle 85\% cjelokupnog broja govornika (www.ethnologue.com), a sve one dvojezične manjine čiji je materinski jezik neslužbeni jezik države su u dvostrukoj mjeri diskriminirani, kao prvo savladali su nestandardizirani oblik materinskoga jezika, a osim toga su okruženi jezikom većinske zajednice. Realizacija deklariranih jezičnih prava i jezične ravnopravnosti iziskuje uporabu manjinskoga jezika kao službenoga, obrazovni i odgojni sustav koji omogućava potpunost školovanja na materinskom jeziku, a i pristup jeziku većinskoga naroda. Reguliranja jezičnih prava ovisi o aktualnoj političkoj ideologiji i često se argumentira kako je to dio unutrašnje politike date države, međutim brojni međunarodni sporazumi, ugovori i dekreti svjedoče o potrebi pravno-političkog konteksta i sugeriraju provedbu zajamčenih prava.

Očuvanje manjinskih jezika osim tih pravnih okvira određuju četiri bitna čimbenika, a to su demografski faktor, tj. govornici datog jezika, situacije, jezični prostor u kojem se jezik osim sakralne funkcije može obavljati i praktičnu funkciju znači ispunjava pravu komunikacijsku potrebu (čimbenik korisnosti), prava koja osiguravaju mogućnost uporabe jezika (politički čimbenik) i namjera govornika, tj. da oni zaista žele koristiti svoj jezik $\mathrm{i}$ prenijeti ga svojim potomcima (simbolična vrijednost) (CSERNICSKOFERENC 2012: 199). U sklopu jezične strategije treba uzeti u obzir sve te čimbenike jer se to usko vezuje uz jezičnu perspektivu manjinske zajednice $\mathrm{i}$ jezične skupine.

U Mađarskoj jezičnoj politici, koja je višejezična, eksplicitna i podržavajuća, središnja mjesta zauzimaju problemi, status i uporaba mađarskoga jezika izvan 
Mađarske, pitanje standardizacije romskog jezika u Mađarskoj, zakonska zaštita znakovnoga jezika te jezična prava manjina.

Polazeći od navedenih rezultata zadnja tri popisa stanovništva jasno je vidljiva diskrepancija između onih koji se izjašnjavaju Hrvatima i onih čiji je materinski jezik hrvatski, smatram da se među zadatcima manjinske jezične politike primarno ističe podržavanje dominancije materinskog jezika ili balansirane dvojezičnosti, a uvjet tomu je realiziranje sociolingvističkih istraživanja, koji se bave raznim segmentima jezične varijabilnosti, dvojezičnosti i višejezičnosti, jezičnoga deficita, jezičnih utjecaja, diglosije, jezične stvarnosti, jezičnoga identiteta i jezične asimilacije, kako bi doprinijeli uspješnom jezičnom planiranju.

\begin{tabular}{|c|l|l|l|}
\hline Godina & $\mathbf{1 9 9 0 .}$ & $\mathbf{2 0 0 1 .}$ & $\mathbf{2 0 1 1 .}$ \\
\hline Narodnost:Hrvat/Hrvatica & 13570 & 15594 & 23561 \\
\hline Materinski jezik: hrvatski & 17326 & 14326 & 13716 \\
\hline
\end{tabular}

(Központi Statisztikai Hivatal, http://www.ksh.hu/docs/hun/xftp/idoszaki/nepsz2011/nepsz_03_00_2011.pdf)

Jezična politika Hrvata danas (2016.) u prvom se planu očituje vezano za pitanje školstva, preuzimanje ustanova, izrade udžbenika i nastavnih pomagala, međutim nedostaju empirijska istraživanja o kognitivnim jezičnim reprezentacijama i o stupnju dvojezičnosti i višejezičnosti, državna mjerenja, jezični korpusi, makrosociolingvistička istraživanja. Pri planiranju zadataka jezične politike Hrvata u Mađarskoj potrebno je uzeti u obzir sociokulturalne čimbenike, odgojno-obrazovnu strukturu i ljudske resurse.

\section{Zaključak}

Dužnost države je da štiti jezični i drugi identitet pripadnika nacionalnih manjina, a ustav bi trebao biti pravni, politički i nacionalni putokaz, kojim je zajamčen pravni okvir prava manjina, ali naglasak je na ostvarivanju prava, do kojih se ne dolazi zbog manjka strategijskih postupaka i jezičnoga planiranja, kao i zbog nedovoljnog naglašavanja kompatibilnih vrijednosti narodnosne biti među kojima se ponajprije ističe dvojezičnost i višejezičnost pojedinca. Uspješnom realiziranju pridonosi proces jezičnoga planiranja, u kojemu je velika odgovornost manjinskih intelektualaca, oni mogu doprinijeti razradi jezične strategije, definiranju novih sadržaja i ciljeva, koji će ujedno poslužiti temeljem izgradnje manjinske jezične politike. 


\section{Literatura}

CSERNICSKÓ - FERENC 2012 = CSERNICSKÓ I. - FERENC V. A kisebbségi nyelvhasználat jogi keretei és azok gyakorlati alkalmazhatósága Kárpátalján // Térvesztés és határtalanítás. A magyar nyelvpolitika 21. századi kihívásai. Nemzetpolitikai Kutatóintézet, Nemzetpolitikai Könyvek 1. Sorozatszerkesztő: Kántor Zoltán. Budapest: Lucidus Kiadó, 2012. 199-236. http://docplayer.hu/3982823-Tervesztes-es-hatartalanitas-a-magyar-nyelvpolitika21-szazadi-kihivasai.html

GUSTAWSON $2001=$ GUSTAWSON S A kisebbségi szláv nyelvek szociolingvisztikai tipológiája // Kisebbségkutatás 10. évf. 1., 2001. http://epa.oszk.hu/00400/00462/00009/25.htm

MAGYARORSZÁG ALAPTÖRVÉNYE = Magyarország Alaptörvénye. Budapest: Magyar Közlöny Lap- és Könyvkiadó Kft., 2016.

ŠKILJAN = ŠKILJAN D. Jezična politika. Zagreb, 1999.

SZÉPE 2001 = SZÉPE GY. Nyelvpolitika: múlt és jövő. Pécs: Iskolakultúra, 2001. 